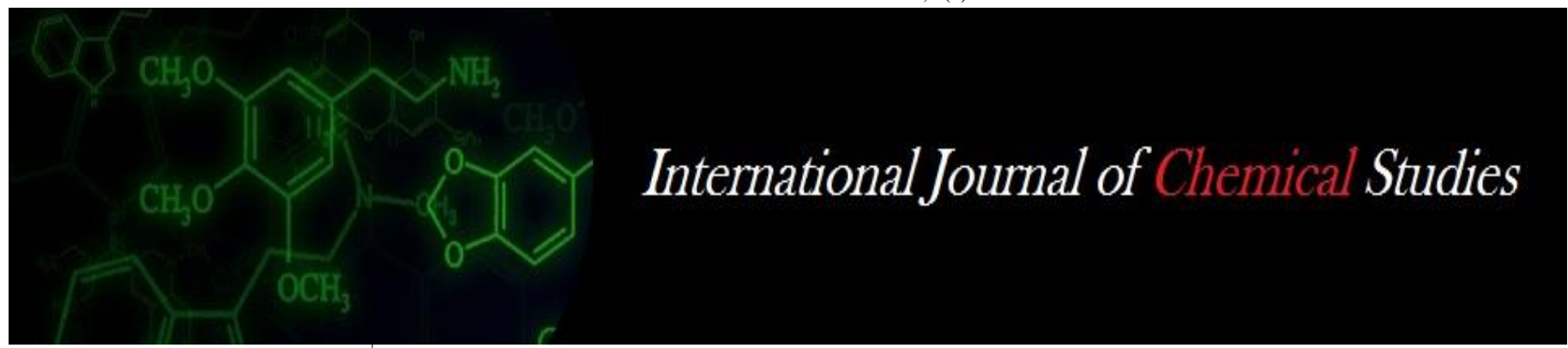

P-ISSN: 2349-8528

E-ISSN: 2321-4902

www.chemijournal.com

IJCS 2021; 9(1): 837-840

(C) 2021 IJCS

Received: 10-10-2020

Accepted: 17-11-2020

Richa Jaswal

Research Scholar, CSKHPKV

Palampur, Kangra, Himachal

Pradesh, India

Sanjeev K Sandal

Principal Scientist, CSKHPKV

Palampur, Kangra, Himachal

Pradesh, India

Corresponding Author:

Richa Jaswal

Research Scholar, CSKHPKV

Palampur, Kangra, Himachal

Pradesh, India

\section{Changes in quality parameters of strawberry fruit through drip irrigation under protected cultivation}

\author{
Richa Jaswal and Sanjeev K Sandal
}

DOI: https://doi.org/10.22271/chemi.2021.v9.i11.11327

\begin{abstract}
The present study was conducted at experimental farm of CSK HPKV, Palampur (Himachal Pradesh), during the year 2015-16 with the objectives of evaluating the effects of drip irrigation and NK fertigation levels on growth and quality of strawberry under protected condition. The treatments comprised of three drip irrigation levels (DI0.6, DI0.8 and $\mathrm{DI}_{1.0}$ ), three NK fertigation levels ( $\mathrm{NK}_{50}, \mathrm{NK}_{75}$ and $\mathrm{NK}_{100}$ ) and Control (C). The results indicated that $\mathrm{DI}_{1.0}$ treatment due to favourable soil moisture regimes led to higher TSS content while vitamin $\mathrm{C}$ was higher in $\mathrm{DI}_{0.6}$. In case of different $\mathrm{NK}$ fertigation treatment, $\mathrm{NK}_{100}$ and $\mathrm{NK}_{75}$ had higher fruit length, breadth, weight and TSS content as compared to $\mathrm{NK}_{50}$ treatment.
\end{abstract}

Keywords: Drip irrigation, strawberry, TSS, Vit. C

\section{Introduction}

Strawberry (Fragaria $\times$ ananassa), one of the most economically important fresh and processed fruits, is cultivated in all arable regions of the globe from the Arctic to the Tropics. It is well known that consumers now pay much more attention to food quality. As a regular part of the diets of millions of people, strawberry is consumed for both its unique flavour and nutrient content through-out the world (Zorrilla-Fontanesi et al., 2011) ${ }^{[25]}$. Strawberry flavour is decided in part by the balance between soluble solids content (SSC) and titratable acid content in ripe fruits. Now, consumers usually prefer sweet strawberries, while sweetness is positively correlated to SSC. Decreasing SSC in strawberries results in lower consumer acceptance of fruits (Keutgen and Pawelzik, 2007) ${ }^{[11]}$, so the SSC value of strawberry fruits is demanded by both consumers and growers.

Strawberries are a good choice among food stuffs containing plentiful amounts of several essential components such as vitamin $\mathrm{C}$, potassium, calcium and magnesium. Cultivation, variety, fertilization, region and weather conditions as well as sampling time and degree of ripeness considerably affect the nutritive value of strawberries (May \& Pritts 1990; Tahvonen 1993; Albregts \& Howard 1978; Albregts \& Howard 1980; May Pritts \& Kelly 1994; Kidmose, Andersen and Vang-Petersen 1996; Haffner, Vestrheim, Jeksrud, \& Tengesdal 1998) $[17,24,1,2,12,18,6]$. Strawberries need moderate fertilization and irrigation and nearly neutral (6-6.5) soil pH. (Hakala et al, 2003) ${ }^{[7]}$.

Culture system and cultural practices such as planting time, groundcover, manuring and irrigation have a great impact on variation of SSC in strawberries (Correia et al., 2011; Jouquand et al. 2008; Kirnak et al. 2003; and Moshiur Rahman et al. 2014) [5, 9, 13, 19]. Fertilizers are extremely important factors in determining strawberry yield and quality. Sufficient nitrogen $(\mathrm{N})$ is essential for normal plant development of strawberry (Papadopoulos, 1987), but high N level can reduced SSC in strawberry fruits (Cantliffe et al., 2007) ${ }^{[4]}$. Potassium $(\mathrm{K})$ is needed in relatively high amounts by strawberries, and high $\mathrm{K}$ treatments often increased significantly SSC in strawberry fruits (Hammad et al., 2014) ${ }^{[8]}$.

Keeping in view the quality and physical parameters of strawberry in Himachal Pradesh, the present study was conducted to evaluate the performance of strawberry cv. Chandler under varying fertigation and drip irrigation levels grown in naturally ventilated polyhouse during October 2015 - May 2016 season. 


\section{Materials and Methods}

An experiment was conducted during 2015-16 with strawberry as a test crop in naturally ventilated polyhouse to study the "Effect of drip irrigation and fertigation on yield and quality of strawberry under protected cultivation" at the experimental farm of CSK Himachal Pradesh Krishi Vishvavidyalaya, Palampur. The average values of physicchemical, OC and chemical properties of $\mathrm{pH}$ of the surface soil (0-0.15 m) were pH 5.67 and organic carbon $12.20 \mathrm{~g} \mathrm{~kg}^{-1}$. The soil was low in available $\mathrm{N}\left(212.0 \mathrm{~kg} \mathrm{ha}^{-1}\right)$, high in available $\mathrm{P}$ (41.65 $\mathrm{kg} \mathrm{ha}^{-1}$ ) and medium in available $\mathrm{K}$ (180.9 $\mathrm{kg} \mathrm{ha}^{-1}$ ).

The nine treatment combinations were imposed in a completely randomized design replicated three times. An additional treatment of control was also kept as an independent module for general comparison of results. The treatments comprised of, (a) Three drip irrigation levels, $\mathrm{DI}_{0.6}$ (Daily drip irrigation at 60 per cent of open pan evaporation), $\mathrm{DI}_{0.8}$ (Daily drip irrigation at 80 per cent of open pan evaporation) and $\mathrm{DI}_{1.0}$ (Daily drip irrigation at 100 per cent of open pan evaporation), (b) Three NK fertigation levels viz., $\mathrm{NK}_{50}(50 \%$ of RDF of which $25 \%$ applied as basal and rest $75 \%$ through fertigation at weekly interval), $\mathrm{NK}_{75}$ (75\% of RDF of which $25 \%$ applied as basal and rest $75 \%$ through fertigation at weekly interval) and $\mathrm{NK}_{100}(100 \%$ of $\mathrm{RDF}$ of which $25 \%$ applied as basal and rest $75 \%$ through fertigation at weekly interval) and (c) Control (C)- 100\% RDF applied through conventional method $(1 / 2 \mathrm{~N}$ and full $\mathrm{PK}$ as basal and remaining $1 / 2 \mathrm{~N}$ in equal split at monthly intervals) with drip irrigation at 1.0 PE.

The FYM @ $2.5 \mathrm{~kg} \mathrm{~m}^{-2}$ was applied to all the treatments. In conventional method, urea, single super phosphate and mureate of potash were used whereas, in fertigation treatments, water soluble fertilizers such as 0:0:50 and urea were applied through drip irrigation system.

Physical parameters of fruit such as Length $(\mathrm{cm})$, breadth (cm) and weight $(\mathrm{g})$, of strawberry fruit were calculated by standard methods. Quality parameters of fruit such as TSS was determined by the hand refrectrometer (A. O. A. C, 1990) [3] and Vitamin C (Ascorbic acid) content was calculated by the titration method with standard dye (2, 6-dichlorophenolindophenol + sodium bicarbonate) as given by Ranganna $(2012)^{[21]}$.

\section{Results and Discussion}

\subsection{Physical parameters of fruit}

The data pertaining to the effects of drip irrigation and NK fertigation levels on fruit length, breadth and weight are given in Table 1.

The fruit length was non-significant under different irrigation schedules. The fruit length values under different NK fertigation levels were $2.7 \mathrm{~cm}, 2.8 \mathrm{~cm}$ and 3.0 in $\mathrm{NK}_{50}, \mathrm{NK}_{75}$ and $\mathrm{NK}_{100}$, respectively. The data showed that $\mathrm{NK}_{75}$ was statistically at par with $\mathrm{NK}_{100}$. Similar results were reported by Kachwaya and Chandel (2015) ${ }^{[10]}$ where fertigation with RDF of NPK gave maximum fruit length. Fruit length was non-significant under 'control' vs. 'others'. The interaction between irrigation and $\mathrm{NK}$ fertigation levels was also nonsignificant.

The fruit breadth was non-significant under different irrigation schedules. Among different NK fertigation levels, the fruit breadth was $2.2 \mathrm{~cm}$ in $\mathrm{NK}_{50}, 2.5$ in $\mathrm{NK}_{75}$ and 2.5 in
$\mathrm{NK}_{100}$. The data showed that fruit breadth was significantly higher in $\mathrm{NK}_{75}$ and $\mathrm{NK}_{100}$ and both were statistically at par. Similar results were reported by Kachwaya and Chandel (2015) [10] where fertigation with RDF of NPK gave maximum fruit breadth. The fruit breadth was non-significant under 'control' vs. 'others'. The interaction between irrigation and NK fertigation levels was also non-significant.

Table 1: Effect of drip irrigation and fertigation on physical parameters at harvest of strawberry

\begin{tabular}{|c|c|c|c|}
\hline Treatments & $\begin{array}{c}\text { Fruit length } \\
(\mathbf{c m})\end{array}$ & $\begin{array}{c}\text { Fruit } \\
\text { breadth(cm) }\end{array}$ & $\begin{array}{c}\text { Fruit weight } \\
\text { (g) }\end{array}$ \\
\hline Drip irrigation & & & \\
\hline $\mathrm{DI}_{0.6}$ & 2.9 & 2.4 & 6.6 \\
\hline $\mathrm{DI}_{0.8}$ & 2.7 & 2.3 & 6.9 \\
\hline $\mathrm{DI}_{1.0}$ & 2.8 & 2.5 & 6.7 \\
\hline $\mathrm{LSD}_{10}(\mathrm{P}=0.05)$ & $\mathrm{NS}$ & $\mathrm{NS}$ & $\mathrm{NS}$ \\
\hline $\begin{array}{c}\text { Fertigation } \\
\text { treatments }\end{array}$ & & & \\
\hline $\mathrm{NK}_{50}$ & 2.7 & 2.2 & 6.4 \\
\hline $\mathrm{NK}_{75}$ & 2.8 & 2.5 & 6.8 \\
\hline $\mathrm{NK}_{100}$ & 3.0 & 2.5 & 7.0 \\
\hline LSD $(\mathrm{P}=0.05)$ & $\mathbf{0 . 2}$ & $\mathbf{0 . 2}$ & $\mathbf{0 . 3}$ \\
\hline Control vs. others & & & \\
\hline $\mathrm{Control}$ & 2.7 & 2.4 & 7.0 \\
\hline Others & 2.8 & 2.4 & 6.7 \\
\hline LSD(P=0.05) & $\mathrm{NS}$ & $\mathrm{NS}$ & $\mathrm{NS}$ \\
\hline
\end{tabular}

The fruit weight values were non-significant under different irrigation schedules. The fruit weight values under different NK fertigation levels were $6.4 \mathrm{~g}, 6.8 \mathrm{~g}$ and 7.0 in $\mathrm{NK}_{50}, \mathrm{NK}_{75}$ and $\mathrm{NK}_{100}$, respectively. The data showed that $\mathrm{NK}_{75}$ was statistically at par with $\mathrm{NK}_{100}$. Similar results were reported by Singh et al. (2013) ${ }^{[23]}$ and Kachwaya and Chandel (2015) ${ }^{[10]}$ where fertigation with RDF of NPK gave maximum fruit weigth. Fruit weight was non-significant under 'control' vs. 'others'.

Table 2: Interaction effect of drip irrigation and NK fertigation on physical parameters of strawberry

\begin{tabular}{|c|c|c|c|c|c|c|c|c|c|}
\hline \multirow{2}{*}{ Drip irrigation } & \multicolumn{3}{|c|}{ Fruit length $(\mathbf{c m})$} & \multicolumn{3}{c|}{ Fruit breadth(cm) } & \multicolumn{3}{c|}{ Fruit weight (g) } \\
\cline { 2 - 11 } & $\mathbf{N K}_{\mathbf{5 0}}$ & $\mathbf{N K}_{\mathbf{7 5}}$ & $\mathbf{N K}_{\mathbf{1 0 0}}$ & $\mathbf{N K}_{\mathbf{5 0}}$ & $\mathbf{N K}_{\mathbf{7 5}}$ & $\mathbf{N K}_{\mathbf{1 0 0}}$ & $\mathbf{N K}_{\mathbf{5 0}}$ & $\mathbf{N K}_{\mathbf{7 5}}$ & $\mathbf{N K}_{\mathbf{1 0 0}}$ \\
\hline $\mathrm{DI}_{0.6}$ & 2.8 & 2.8 & 3.1 & 2.2 & 2.5 & 2.5 & 6.7 & 6.3 & 6.9 \\
\hline $\mathrm{DI}_{0.8}$ & 2.6 & 2.7 & 2.9 & 2.1 & 2.4 & 2.4 & 6.0 & 7.2 & 7.3 \\
\hline $\mathrm{DI}_{1.0}$ & 2.7 & 2.8 & 3.0 & 2.4 & 2.5 & 2.5 & 6.4 & 6.8 & 6.9 \\
\hline $\mathrm{LSD}(\mathrm{P}=0.05)$ & \multicolumn{3}{|c|}{$\mathrm{NS}$} & \multicolumn{3}{c|}{$\mathrm{NS}$} & \multicolumn{3}{c|}{0.6} \\
\hline
\end{tabular}

The data on interaction between drip irrigation and NK fertigation levels showed that $\mathrm{DI}_{0.6} \mathrm{NK}_{50}, \mathrm{DI}_{0.8} \mathrm{NK}_{75}, \mathrm{DI}_{1.0} \mathrm{NK}_{75}$ and $\mathrm{DI}_{1.0} \mathrm{NK}_{100}$ were statistically at par with $\mathrm{DI}_{0.8} \mathrm{NK}_{100}$.

\subsection{Quality parameters}

The data pertaining to the effects of drip irrigation and NK fertigation levels on TSS content and vitamin C content at harvest are given in Table 3.

The TSS content under different irrigation levels was significantly higher under $\mathrm{DI}_{1.0}\left(10.0^{0} \mathrm{~B}\right)$ followed by $\mathrm{DI}_{0.8}$ $\left(8.5^{\circ} \mathrm{B}\right)$ and lowest in $\mathrm{DI}_{0.6}\left(7.9^{\circ} \mathrm{B}\right)$. This may be due to better root and shoot growth leading to more uptake of nutrients and water that resulted in high TSS content. Similar results were reported by Kumar et al. (2012) ${ }^{[14]}$ where TSS $(7.981 \%)$ content was higher under $\mathrm{I}_{1}(\mathrm{IW} / \mathrm{CPE}=1)$ treatment than other irrigation levels. The TSS values under different NK fertigation levels were $8.0^{\circ} \mathrm{B}, 9.3^{\circ} \mathrm{B}$ and $9.1^{\circ} \mathrm{B}$ in $\mathrm{NK}_{50}, \mathrm{NK}_{75}$ and NK100, respectively. 
Table 3: Effect of drip irrigation and NK fertigation on TSS and vitamin $\mathrm{C}$ content

\begin{tabular}{|c|c|c|}
\hline . Treatments & TSS $\left({ }^{\mathbf{0}} \mathbf{B}\right)$ & $\begin{array}{c}\text { Vitamin C }(\mathbf{m g ~ 1 0 0} \\
\left.\mathbf{g}^{-1}\right)\end{array}$ \\
\hline \multicolumn{3}{|c|}{ Drip irrigation } \\
\hline $\mathrm{DI}_{0.6}$ & 7.9 & 67.1 \\
\hline $\mathrm{DI}_{0.8}$ & 8.5 & 64.5 \\
\hline $\mathrm{DI}_{1.0}$ & 10.0 & 51.1 \\
\hline $\mathrm{LSD}(\mathrm{P}=0.05)$ & 1.0 & 3.2 \\
\hline \multicolumn{3}{|c|}{ Fertigation treatments } \\
\hline $\mathrm{NK}_{50}$ & 8.0 & 60.2 \\
\hline $\mathrm{NK}_{75}$ & 9.3 & 61.8 \\
\hline $\mathrm{NK}_{100}$ & 9.1 & 60.7 \\
\hline LSD $(\mathrm{P}=0.05)$ & 0.7 & $\mathrm{NS}$ \\
\hline \multicolumn{3}{|c|}{ Control vs. others } \\
\hline Control & 8.3 & 41.6 \\
\hline Others & 8.8 & 60.9 \\
\hline LSD $(\mathrm{P}=0.5)$ & $\mathrm{NS}$ & 3.4 \\
\hline
\end{tabular}

The data further, showed that $\mathrm{NK}_{100}$ was statistically at par with $\mathrm{NK}_{75}$. Similar results were reported by Kachwaya and Chandel (2015) ${ }^{[10]}$ where fertigation with $100 \%$ RDF of NPK gave highest TSS. The TSS values were non-significant in 'control' vs. 'others'. The interaction between irrigation and $\mathrm{NK}$ fertigation levels except $\mathrm{DI}_{0.6} \mathrm{NK}_{50}, \mathrm{DI}_{0.6} \mathrm{NK}_{100}$ and $\mathrm{DI}_{0.8} \mathrm{NK}_{50}$ was statistically at par with $\mathrm{DI}_{0.8} \mathrm{NK}_{100}$.

Vitamin $\mathrm{C}$ content determined under different irrigation levels was $67.1 \mathrm{mg} 100^{-1} \mathrm{~g}^{-1}$ in $\mathrm{DI}_{0.6}, 64.5 \mathrm{mg} 100^{-1} \mathrm{~g}^{-1}$ in $\mathrm{DI}_{0.8}$ and $51.1 \mathrm{mg} 100^{-1} \mathrm{~g}^{-1}$ in $\mathrm{DI}_{1.0}$. The data showed that vitamin $\mathrm{C}$ content in $\mathrm{DI}_{0.8}$ was statistically at par with $\mathrm{DI}_{0.6}$.

Similar results were reported by Kumar et al. (2005) [16]; Sharma et al. (2005) ${ }^{[22]}$ and Kumar and Dey (2012) ${ }^{[15]}$ where increased amount of irrigation water decreased the vitamin $\mathrm{C}$ content in fruit.

Vitamin C was non-significant under different NK fertigation levels. However, it was significantly higher in 'others' (60.9 $\mathrm{mg} 100^{-1} \mathrm{~g}^{-1}$ ) compared to 'control' (41.6 mg $\left.100^{-1} \mathrm{~g}^{-1}\right)$. The interaction between irrigation and $\mathrm{NK}$ fertigation levels showed that $\mathrm{DI}_{0.6} \mathrm{NK}_{100}$, and $\mathrm{DI}_{0.8} \mathrm{NK}_{50}$ were statistically at par with $\mathrm{DI}_{0.6} \mathrm{NK}_{75}$.

Table 4: Interaction effect of drip irrigation and NK fertigation on TSS and vitamin C content

\begin{tabular}{|c|c|c|c|c|c|c|}
\hline \multirow{2}{*}{ Drip irrigation } & \multicolumn{3}{|c|}{$\operatorname{TSS}\left({ }^{0} \mathrm{~B}\right)$} & \multicolumn{3}{|c|}{ Vitamin $\mathrm{C}\left(\mathrm{mg}^{100^{-1}} \mathrm{~g}^{-1}\right)$} \\
\hline & $\mathbf{N K}_{50}$ & $\mathbf{N K}_{75}$ & $\mathrm{NK}_{100}$ & $\mathrm{NK}_{50}$ & $\mathbf{N K}_{75}$ & $\mathbf{N K}_{100}$ \\
\hline $\mathrm{DI}_{0.6}$ & 7.7 & 9.1 & 7.0 & 59.4 & 71.7 & 70.1 \\
\hline $\mathrm{DI}_{0.8}$ & 6.5 & 8.9 & 10.3 & 68.1 & 64.9 & 60.6 \\
\hline $\mathrm{DI}_{1.0}$ & 9.9 & 10.0 & 10.0 & 53.3 & 48.7 & 51.3 \\
\hline $\operatorname{LSD}(\mathrm{P}=0.05)$ & \multicolumn{3}{|c|}{1.4} & \multicolumn{3}{|c|}{4.5} \\
\hline
\end{tabular}

\section{Conclusion}

Based on the study, the following conclusion was drawn:

By increasing the irrigation levels from $\mathrm{DI}_{0.6}$ to $\mathrm{DI}_{1.0}$, there was improvement in TSS content. However, increased amount of irrigation water decreased the vitamin $C$ content in fruits. Similarly, when the fertigation level increased from $\mathrm{NK}_{50}$ to $\mathrm{NK}_{100}$, there was also improvement in TSS content, fruit length, breadth and weight.

\section{Acknowledgment}

The author sincerely thanks All India Coordinated Research Project (AICRP) on Integrated Watershed Management (IWM) for financial support for carrying out the present study.

\section{References}

1. Albregts E, Howard C. Elemental composition of fresh strawberries fruit. Journal of the American Horticultural Science 1978;103:293-296.

2. Albregts E, Howard C. Accumulation of nutrients by strawberry plants and fruit grown in annula hill culture. Journal of the American Horticultural Science 1980;105:386-388.

3. AOAC. Official Methods of Analysis: Association of Analytical Chemists (16 ${ }^{\text {th }}$ Ed.). Arlington Virginia, USA 1990.

4. Cantliffe DJ, Castellanos JZ, Paranjpe AV. Yield and quality ofgreenhouse grown strawberries as affected by nitrogen level in coco coir andpine bark media. Proc. Fla. State Hortic. Soc 2007;120:157-161.

5. Correia PJ, Pestana M, Martinez F, Ribeiro E, Gama F, Saavedra $\mathrm{T}$ et al. Relationships between strawberry fruit quality attributes and crop load. Sci. Hortic. 2011;130:398-403.

6. Haffner K, Vestrheim S, Jeksrud WK, Tengesdal G. 1ascorbic acid and other quality criteria in frozen and dehydrated strawberries Fragaria $x$ ananassa Duch. Nahrung 1998;4(1):32-35.

7. Hakala M, Lapvetelaine A, Huopalahti R, Kallio H, Tahvonen R. Effects of varieties and cultivation conditions on the composition of strawberries. Journal of Food Composition and Analysis 2003;16:67-80

8. Hammad S, Elzehery $\mathrm{T}$, Ramadan A. Influence of compost: effectivemicroorganisms (EM) and potassium on strawberry production in sandy soils.Acta Hortic. 2014;1049:407-414.

9. Jouquand C, Chandler C, Plotto A, Goodner K. A sensory and chemicalanalysis of fresh strawberries over harvest dates and seasons reveals factorsthat affect eating quality. J. Am. Soc. Hortic. Sci 2008;133:859-867.

10. Kachwaya DS, Chandel. Effect of fertigation on growth,yield,fruit quality and leaf nutrients content of strawberry (Fragaria $\times$ ananassa) cv Chandler. The Indian Journal of Agricultural Sciences 2015, 85

11. Keutgen A, Pawelzik E. Modifications of taste-relevant compounds instrawberry fruit under $\mathrm{NaCl}$ salinity. Food Chem 2007;105:1487-1494.

12. Kidmose U, Andersen H, Vang-Petersen O. Yield and quality attributes of strawberry cultivars grown in Denmark 1990-1991. Fruit-Varieties-Journal 1996;50(3):160-167.

13. Kirnak H, Kaya C, Higgs D, Bolat I, Simsek M, Ikinci A. Effects ofpreharvest drip-irrigation scheduling on strawberry yield quality and growth. Aust. J. Exp. Agr. 2003;43:105-111.

14. Kumar PS, Choudhary VK, Bhagawati R. Influence of mulching and irrigation level on water -use efficiency, plant growth and quality of strawberry (Fragariax ananassa). Indian Journal Of Agricultural Sciences 2012;82:127-33

15. Kumar S, Dey P. Influence of soilhydrothermal environment, irrigation regime, and different mulches on the growth and fruit quality of strawberry (Fragariax ananassa L.) plants in a sub-temperate climate. Journal of Horticultural Science and Biotechnology 2012;87:374380

16. Kumar S, Sharma IP, Raina JN. Effect of levels and application methods of irrigation and mulch materials on strawberry production in north-west Himalayas. Journal of the Indian Society of Soil Science 2005, 53 
17. May G, Pritts M. Strawberry nutrition. Advances in Strawberry Production 1990;9:10-23.

18. May G, Pritts M, Kelly M. Seasonal patterns of growth and tissue nutrient content in strawberries. Journal of Plant Nutrition 1994;17:1149-1162.

19. Moshiur Rahman M, Rahman MM, Hossain MM, Khaliq QA, Moniruzzaman M. Effect of planting time and genotypes growth: yield and quality ofstrawberry (Fragaria $\times$ ananassa Duch). Sci. Hortic. 2014;167:56-62.

20. Papadopoulos I. Nitrogen fertigation of greenhousegrown strawberries. Fertil. Res 1987;13:269-276.

21. Ranganna S. Handbook of Analysis and Quality Control for Fruit and Vegetable Products. Tata McGraw Hill Education Private Limited, New Delhi, Inc. 2012, 105106

22. Sharma IP, Kumar S, Kumar P. Effect of drip irrigation and mulches on yield, quality and water - use efficiency in strawberry under mid hill conditions. Acta Horticulturae 2005, 696.

23. Singh A, Gulati IJ, Chopra R. Effect of various fertigation schedules and organic manures on tomato (Lycopersicon esculentum mill.) yield under arid condition. An international quarterly journal of life sciences 2013;8:1261-1264.

24. Tahvonen R. Contents of selected elements in some fruits, berries and vegetables on the Finnish market in 1987-1989. Journal of Food Composition and Analysis, 1993;6:75-86.

25. Zorrilla-Fontanesi Y, Cabeza A, Domínguez P, Medina JJ, Valpuesta V, Denoyes-Rothan B et al. Quantitative trait loci and underlying candidate genes controlling agronomical and fruit qualitytraits in octoploid strawberry (Fragaria $\times$ ananassa). Theor. Appl. Genet. 2011;123,755-778. 